\title{
Colorectal Cancer in the Family: Psychosocial Distress and Social Issues in the Years Following Genetic Counselling
}

\author{
Eveline M.A. Bleiker', Fred H. Menko², Irma Kluij ${ }^{3}$, Babs G. Taal ${ }^{4}$, Miranda A. Gerritsma', Lidwina D.V. Wever', Neil K. Aaronson' \\ 1Division of Psychosocial Research and Epidemiology, The Netherlands Cancer Institute, Amsterdam \\ 2Department of Clinical Genetics and Human Genetics, VU University Medical Center, Amsterdam \\ 3 Department of Clinical Genetics, Academic Medical Center, Amsterdam \\ ${ }^{4}$ Department of Gastroenterology, The Netherlands Cancer Institute, Amsterdam
}

Key words: colorectal cancer, HNPCC, genetic counselling, psychosocial impact

Corresponding author: Eveline M.A. Bleiker, Division of Psychosocial Research and Epidemiology, Netherlands Cancer Institute, Plesmanlaan 121, 1066 CX Amsterdam, The Netherlands, tel.: +31-20-512.6072, fax: +31-20-512.2322, e-mail: e.bleiker@nki.nl

Submitted: 2 May 2007

Accepted: 22 May 2007

\begin{abstract}
Background: This study examined: (1) levels of cancer-specific distress more than one year after genetic counselling for hereditary nonpolyposis colorectal cancer (HNPCC); (2) associations between sociodemographic, clinical and psychosocial factors and levels of distress; (3) the impact of genetic counselling on family relationships, and (4) social consequences of genetic counselling.

Methods: In this cross-sectional study, individuals who had received genetic counselling for HNPCC during 1986-1998 completed a self-report questionnaire by mail.

Results: 116 individuals (81\% response rate) completed the questionnaire, on average 4 years after the last counselling session. Of all respondents, $6 \%$ had clinically significant levels of cancer-specific distress (Impact of Event Scale, IES). Having had contact with a professional psychosocial worker for cancer risk in the past 10 years was significantly associated with higher levels of current cancer specific distress. Only a minority of the counselees reported any adverse effects of genetic counselling on: communication about genetic counselling with their children (9\%), family relationships (5\%), obtaining life insurance (8\%), choice or change of jobs (2\%), and obtaining a mortgage (2\%).

Conclusion: On average, four years after genetic counselling for HNPCC, only a small minority of counselled individuals reports clinically significant levels of distress, or significant family or social problems.
\end{abstract}

\section{Introduction}

Between 1 and $6 \%$ of all colorectal cancers represent a well-delineated genetic syndrome, hereditary nonpolyposis colorectal cancer (HNPCC or Lynch syndrome) [1, 2]. Before 1993, cancer risk estimates and colon screening recommendations were based on family history only [3]. Since 1993, genetic testing for HNPCC has been possible for at-risk families [4-7]. Carriers of HNPCC-related mutations have a lifetime risk of up to $80 \%$ of developing colorectal cancer [8]. Those meeting the clinical criteria for HNPCC [9] and 
the proven carriers of HNPCC-related mismatch repair (MMR) genes are advised to undergo a colonoscopy every $1-2$ years [10]. In a recent paper, we reported on compliance with recommended colon-screening advice [1 1]. The focus of the current paper is on the long-term psychosocial impact of genetic counselling for hereditary nonpolyposis colorectal cancer.

Most studies on the psychosocial consequences of genetic counselling and testing for breast or colorectal cancer have not shown significantly increased mean levels of psychological distress during the 12 months immediately following testing [12-22]. However, despite the fact that mean levels of distress are not increased, it has been reported that $3 \%$ to $24 \%$ of individuals experience heightened levels of distress after genetic counselling and/or testing for colorectal cancer [16-18]. Factors that are reported to be associated with heightened levels of distress during or after counselling or testing include: high perceived cancer risk [23], younger age [23], education level [18, 23] (with conflicting findings with regard to the direction of the association), female gender [18], baseline mood disturbance [19], genetic test result (carriers and those awaiting test results) [16], fewer sources of social contacts $[18,19]$, and less satisfaction with those contacts [18].

Most studies on genetic counselling for cancer have generally focused on the first 12 months after counselling $[12,13]$. However, in order to better counsel high-risk families, we need to understand the long-term impact of undergoing genetic counselling and mutation testing [24].

Genetic counselling may not only affect the individual being counselled, but also family relationships [25]. Although most individuals from HNPCC families have been found to be willing to share information about HNPCC with family members [26], the initial clinic attendee may find it particularly difficult to inform relatives, especially distant relatives $[27,28]$ or in emotionally distant relationships [29], since the information may have a disturbing impact on family relationships [30]. However, no information is currently available on the extent to which genetic counselling affects family relationships in the years following genetic counselling and testing for HNPCC [31].

Information provided during genetic counselling/ testing may also have significant consequences in the areas of insurance, employment and family planning [32]. A common concern is that personal information about the results of genetic counselling may be required by insurance companies, and that this may result in limited coverage, increased costs, or outright denial of insurance [33]. This fear of insurance discrimination has been reported to be associated with the decision not to undergo genetic testing for breast cancer; however, no evidence of actual insurance discrimination from BRCAl/2 testing has been observed [34].

Discriminatory practices related to employment, life-insurance or obtaining a mortgage have not yet been documented in the Netherlands and, to our knowledge, no systematic study of this issue has been carried out in this area of cancer genetics. Only one Finnish study reported on individuals tested for HNPCC: no differences were found between carriers and noncarriers in life or health insurance coverage within 12 months after genetic counselling and testing [35].

Finally, with regard to family planning, it has been reported that individuals who tested positive for a BRCA1 gene mutation had more negative attitudes towards reproductive intentions than non-carriers [36]. To our knowledge, no studies have investigated this issue in HNPCC.

The present study was carried out to investigate: (1) levels of cancer-specific distress more than one year after genetic counselling for HNPCC; (2) the association between sociodemographic, clinical and psychosocial factors and levels of distress; (3) the impact of genetic counselling on family relationships; and (4) social consequences of genetic counselling.

\section{Methods}

\section{Participants}

This cross-sectional study recruited all individuals who were counselled between 1986 and 1998 at one of three family cancer clinics in Amsterdam for HNPCC. These individuals represent a clinical case series. The participating hospitals were the VU University Medical Center (VUMC), the Netherlands Cancer Institute Antoni van Leeuwenhoek Hospital (NKI-AVL), and the Academic Medical Center (AMC). Included were all individuals who met the Amsterdam-I criteria, [9] and had completed genetic counselling for HNPCC. Additional inclusion criteria were basic fluency in Dutch, having had at least one face-to-face counselling session with a clinical geneticist (physician), having been informed about the risk of developing colorectal cancer (again), and not being in a terminal stage of illness.

\section{Genetic counselling}

In this paper we use the term "genetic counselling" to refer to the entire counselling process. This includes an intake session during which a pedigree is obtained, and one or more counselling sessions with a genetic counsellor or clinical geneticist during which 
a diagnosis is made, risk counselling is provided, and preventive health recommendations are discussed. The risk estimation can be based on the family history only, or also on the results of a DNA test. If a family meets the clinical criteria for HNPCC [9] DNA testing (testing for MMR genes) is usually offered.

\section{Procedures}

All eligible individuals received a letter from their clinical geneticist explaining the aim of the study, and a self-report questionnaire. The completed questionnaire could be returned in a postage-free envelope. If the questionnaire was not returned within three weeks, a reminder and a copy of the questionnaire were sent. The study was approved by the institutional review boards of the three participating hospitals.

\section{Measures}

Sociodemographic and clinical data: The following data were obtained from the medical records and/or the questionnaire: age, gender, marital status, level of education, number and age of children, personal history of cancer (i.e. treated for cancer, treated for benign polyps, not treated for cancer); actual cancer risk (1. proven carrier of HNPCC mutation, 2. clinical diagnosis of HNPCC, i.e. meeting the Amsterdam-I criteria, and 3. non-carrier, i.e. mutation-negative in a family with a proven pathogenic mutation); and dates and number of counselling sessions.

Perceived risk: Respondents were asked to report their perceived risk of developing cancer (again) relative to that of the "average person in the Dutch population" (item adapted from Lerman, Seay, et al. [37]). The response categories were: "much higher", "somewhat higher", "the same", and "lower".

Involvement in the disease process of a relative: Since personal involvement in the illness experience of a relative is hypothesized to be related to the level of cancer-related distress [38], respondents were first asked to report the number of first and second degree relatives with colorectal cancer, and then the extent to which they were involved in the disease process of one or more of those relatives (response categories: "very much", "quite a bit", "a little", "not at all").

Professional support: To investigate whether professional psychological counselling for cancer worries during the past 10 years (with a psychologist, psychiatrist, social worker or general practitioner) was associated with present levels of distress, a comparison was made between those who had ever had such contact during the past 10 years and those who had never had such contact in that period.
Cancer-specific distress: The Intrusion subscale of the Impact of Event Scale (IES) [39] was used to assess the frequency and severity of intrusive thoughts about the familial occurrence of colorectal cancer. The Intrusion scale consists of seven Likert-type items (response categories: "not at all" to "often"). The Dutch translation of the IES [40] has proven to be a valid and reliable instrument for assessing event-specific psychological distress (Cronbach's alpha of the Intrusion subscale in the present study $=0.89$ ). The Intrusion subscale has also proven to be a valid and reliable instrument in populations at increased risk of developing hereditary breast cancer $[41,42]$. In the present study "the event" was defined as "cancer in the family". The items were related to this situation. The cut-off score of 20 on the IES subscale was used to indicate a "clinically important reaction" $[43,44]$.

Consequences for family relationships: Respondents were first asked whether their relationship with family members had changed due to the genetic counselling process (response categories: "improved", "deteriorated", "changed but not for the better or worse", "no change"). Three additional questions were posed regarding communication with relatives about the genetic counselling process, i.e. did the respondent experience problems: with (1) first-degree relatives (siblings, parents), (2) their children, or (3) second-degree relatives (response categories: yes, no, not applicable).

Consequences for future planning and social issues: Respondents were asked a single question about whether the genetic counselling had had an impact on their plans for having children. Additionally, a series of questions was posed as to whether, due to the genetic counselling, problems had been experienced with intimate relationships, choice or change in employment, obtaining a mortgage, or obtaining life insurance (response categories for each topic: yes, no, not applicable). These questions were based on a questionnaire used previously in a study of long-term survivors of Hodgkin's lymphoma [45].

\section{Statistical analyses}

Descriptive statistics were generated to characterize the study sample in terms of demographics and clinical background, and to describe the experienced consequences of genetic counselling. Levels of cancerspecific distress were examined as a function of sociodemographic, clinical and psychosocial variables.

Depending on the level of measurement and number of categories, Student's t-test, chi-square statistic or analyses of variance were used. In the case of multiple comparisons, the post-hoc Scheffe test was 
used to investigate subgroup differences. A regression analysis was carried out to determine which variables were significantly (i.e. $\mathrm{p}<0.05$ ) associated with psychological distress following the genetic counselling. In this analysis, sociodemographic variables (age, gender, level of education), clinical variables (personal history of cancer, actual risk, time since last counselling, number of face-to-face counselling sessions with clinical geneticist) and psychosocial variables (perceived risk, professional support in the past, involvement in disease process of relative) were entered in the model. To control for potential clustering effects caused by the fact that some participants were members of the same family, a general linear model

Table 1. Sociodemographic and clinical characteristics of respondents $(\mathrm{N}=116)$

\begin{tabular}{lcc}
\hline Characteristics & N & $\%$ \\
\hline $\begin{array}{l}\text { gender } \\
\text { male }\end{array}$ & 60 & 52 \\
\hline female & 56 & 48
\end{tabular}

\begin{tabular}{lcc}
\hline level of education & & \\
\hline low & 40 & 35 \\
\hline moderate & 43 & 37 \\
\hline high & 32 & 28 \\
\hline missing & 1 & - \\
\hline
\end{tabular}

treated for cancer

\begin{tabular}{lll} 
yes & 21 & 18 \\
\hline benign polyp & 25 & 22 \\
\hline no & 70 & 60 \\
\hline
\end{tabular}

actual risk

\begin{tabular}{lll} 
mutation carriers & 31 & 27 \\
\hline clinical diagnosis of HNPCC & 60 & 52 \\
\hline non-carrier & 25 & 22
\end{tabular}

time since last counselling (years)

\begin{tabular}{lcc} 
mean (SD) & 3.8 & $(2.3)$ \\
\hline median (range) & 3 & $(1-11)$ \\
\hline number of counselling sessions & & \\
mean (SD) & 2.4 & $(2.0)$ \\
\hline 1 & 32 & 29 \\
\hline 2 or more & 84 & 71 \\
\hline
\end{tabular}

for regression analyses was used, inputting family membership as a random factor in the model.

\section{Results}

\section{Response}

In total, 143 individuals who were counselled for HNPCC in the period 1986 to 1998 were invited to participate in the study. Of these, $116(81 \%)$ completed the questionnaire. The respondents were, on average, older than the non-respondents (mean age $=43.4$ years $(s d=11.2)$ versus 37.9 years $(s d=13.0) ; p=0.05)$. No statistically significant differences were found between the respondents and the non-respondents for gender, personal history of cancer, risk of developing cancer, hospital, or number of affected first-degree relatives. The 116 respondents stemmed from 29 families.

\section{Sociodemographic and clinical characteristics}

Table 1 shows that, in the responding group, men never had any signs (precursors) of colorectal cancer. In total, 31 individuals were found to be a carrier of an HNPCC mutation (20 hMLH1, 11 hMSH2). Twenty-five individuals were found not to be a carrier of a known mutation in their family (non-carriers). In addition, the mutation status of 60 individuals was unknown; however, their family history was consistent with HNPCC. Of this group, 12 had themselves undergone genetic testing for MMR mutations, resulting in an inconclusive test result. Others had not undergone testing themselves. No statistically significant differences in distress levels were found between those individuals classified as "clinical HNPCC" who had and who had not undergone genetic testing. For this reason, and because of their comparable risk estimation and screening advice, these counselees were taken together as one group.

The mean time elapsed between the final counselling session and the completion of the questionnaire was 3.8 years $(s d=2.3)$. Prior to the contacts with the clinical geneticist most individuals had had a standard intake session with a genetic nurse. In addition, $29 \%$ of the respondents had a single face-to-face counselling session with the clinical geneticist (physician); the remaining $71 \%$ had two or more such sessions.

\section{Distress}

The mean score on the IES-Intrusion subscale was $5.3(s d=6.9 ; n=108)$. Six percent $(n=6)$ scored above the cut-off score of 20 , indicating a clinically significant and women were equally represented, and $60 \%$ had 
level of cancer-specific distress $(1$ carrier, 4 clinical HNPCC, 1 non-carrier). Table 2 displays the mean scores and standard deviations on the distress scale as a function of various sociodemographic and clinical characteristics. Those who had received professional psychosocial support in the past reported significantly higher levels of current cancer-specific distress $(p=0.002)$ than those who did not receive such support. In addition, those who had been treated for cancer or a benign polyp tended to report more cancer-specific distress than healthy individuals $(p=0.06)$. No statistically significant differences were found in levels of cancerspecific distress as a function of age, gender, level of education, actual or perceived cancer risk, close involvement in the disease process of one or more relatives, or time since last counselling.

In the regression analysis, only one variable was found to be significantly associated with cancer-specific distress at the multivariate level: "having had contact with a professional psychosocial worker in the past 10 years for cancer risk" $(p=0.05)$. Gender was not significantly associated with cancer-specific distress, but women tended to report more distress then men $(p=0.06)$.

\section{Consequences of counselling for family relationships}

Table 3 shows that 7 (9\%) of the 79 individuals with children experienced problems in communication about genetic counselling with their children. Additionally, 7 respondents (7\%) reported experiencing problems in discussing this issue with their first-degree relatives, and another 7 (8\%) with their second-degree relatives.

Of the 109 counselees who answered the questions on family relationships, five (5\%) reported that family relationships had worsened as a result of genetic counselling. In 12 cases (11\%) relationships had improved, and in another 14 (13\%) relationships had changed, but not for the better or the worse. For the majority of the respondents genetic counselling had had no significant impact on family relationships.

\section{Consequences of genetic counselling for social issues}

Only 3 respondents (5\%) reported that genetic counselling had had an impact on family planning (none were carriers), only 1 respondent (2\%) reported having experienced a problem with employment, and 1 respondent reported problems (2\%) in obtaining a mortgage. Five individuals (8\%), with diverse actual risks, had experienced a problem in obtaining life insurance due to genetic counselling.
Table 2. Levels of cancer-related distress (IES-intrusion, $n=108^{*}$ ) as a function of sociodemographic, clinical and psychosocial factors

\begin{tabular}{lllll}
\hline Characteristics & \multicolumn{4}{c}{ IES } \\
\cline { 2 - 5 } & $n$ & mean & (sd) & p-value \\
\hline
\end{tabular}

age

\begin{tabular}{lllll}
$20-35$ years & 30 & 5.2 & $(6.1)$ & \\
\hline $36-50$ years & 48 & 4.4 & $(5.8)$ & 0.31 \\
\hline $51-75$ years & 30 & 6.9 & $(8.8)$ &
\end{tabular}

gender

\begin{tabular}{lllll} 
male & 58 & 4.6 & $(7.0)$ & 0.24 \\
\hline female & 50 & 6.1 & $(6.7)$ &
\end{tabular}

level of education

\begin{tabular}{lcccc} 
low & 37 & 6.3 & $(7.9)$ & \\
\hline middle & 40 & 6.0 & $(7.2)$ & 0.12 \\
\hline high & 30 & 3.1 & $(4.5)$ & \\
\hline
\end{tabular}

actual risk

\begin{tabular}{lcccc} 
mutation carriers & 29 & 5.9 & $(5.8)$ & \\
\hline clinical HNPCC & 56 & 5.7 & $(7.6)$ & 0.47 \\
\hline non-carriers & 23 & 3.7 & $(6.3)$ &
\end{tabular}

perceived risk

\begin{tabular}{lcccc} 
much higher & 32 & 5.2 & $(6.2)$ & \\
\hline somewhat higher & 36 & 5.2 & $(6.0)$ & 0.96 \\
\hline same & 31 & 4.8 & $(6.8)$ & \\
\hline lower & 6 & 3.8 & $(6.4)$ &
\end{tabular}

treated for cancer

\begin{tabular}{lllll} 
yes & 20 & 7.5 & $(6.9)$ & \\
\hline benign polyp & 23 & 7.0 & $(8.9)$ & 0.06 \\
\hline no & 65 & 4.1 & $(5.8)$ & \\
\hline
\end{tabular}

professional support

\begin{tabular}{lllll} 
ever & 16 & 10.1 & $(6.8)$ & 0.002 \\
\hline never & 91 & 4.4 & $(6.6)$ & \\
\hline
\end{tabular}

involvement in disease process of relative

\begin{tabular}{lcccc} 
very much & 63 & 6.3 & $(6.8)$ & \\
\hline quite a bit & 23 & 5.4 & $(6.5)$ & 0.24 \\
\hline a little/not at all & 21 & 3.6 & (7.3) &
\end{tabular}

* Due to missing values for some of the variables, the total number of individuals in these analyses is 108 . 
Table 3. Family communication and social issues

\begin{tabular}{ccc}
\hline Questions & $\begin{array}{c}\text { applicable } \\
\text { to total }\end{array}$ & $\mathrm{n}$ \\
$\mathrm{N}$ & $\%$
\end{tabular}

Did you experience problems in talking about genetic counselling...

\begin{tabular}{lccc} 
- to your children & 79 & 7 & 9 \\
\hline $\begin{array}{c}\text { - to } \text { 1st degree relatives }^{\text {(parents, brothers, sisters) }} \\
\text { - to 2nd degree relatives }\end{array}$ & 103 & 7 & 7 \\
\hline
\end{tabular}

Did you experience changes in relationships with relatives due to genetic counselling?

\begin{tabular}{lccc} 
- worse with some relatives & 109 & 5 & 5 \\
\hline - improved with some relatives & 109 & 12 & 11 \\
\hline - changed, but not better or worse & 109 & 14 & 13 \\
\hline - no change in relationships & 109 & 81 & 74 \\
\hline
\end{tabular}

Did you experience problems due to genetic counselling in...

\begin{tabular}{llll} 
- family planning & 56 & 3 & 5 \\
\hline - (getting a) relationship & 66 & 0 & - \\
\hline - choice or change of job & 67 & 1 & 2 \\
\hline - obtaining a mortgage & 67 & 1 & 2 \\
\hline - obtaining life insurance & 66 & 5 & 8
\end{tabular}

\section{Discussion}

This study is the first to report the results of a longterm (i.e. more than one year) follow-up of the psychosocial consequences of genetic counselling for familial colorectal cancer.

\section{Distress}

On average, four years after the completion of genetic counselling and/or testing for colorectal cancer, only a small minority $(6 \%)$ of counselled individuals reported having clinically significant levels of cancerspecific distress. These rates are comparable to those reported by Coyne et al. [46] in a study of women at high-risk for breast cancer.

Previous contact with a professional psychosocial worker for cancer risk was associated significantly with current levels of cancer-specific distress. The most plausible explanation might be that those most distressed are most likely to seek psychosocial help and that psychological distress is stable and persists over time. This explanation is in line with the results of the review of Broadstock et al. [12] and the study of
Gritz et al. [19], who found pre-genetic test mood disturbance and lower quality of life to be the only significant predictors of distress after genetic counselling. However, it should be noted that the mean score of the distressed group was still below the cutoff score to be of clinical relevance.

One might argue that the assessment of "previous contact with a psychosocial worker" is a proxy for distress. However, we assessed current levels of cancerspecific distress, versus previous psychosocial support during the past 10 years, indicating only a possible partial overlap. Furthermore, when excluding the variable "previous support" from the regression analyses, the only factor associated with cancer-specific distress was female gender $(p=0.02)$. Higher selfreported levels of distress among women have been reported in previous studies [47-50]. No other variables contributed significantly to the prediction of cancer-specific distress at the multivariate level, although, at the univariate level, cancer history tended to be associated with cancer-specific distress.

It has previously been reported that a higher perceived breast cancer risk is associated with higher levels of distress in high-risk women [51]. Our findings do not confirm these results in the case of colorectal cancer. This might suggest that those at risk for colorectal cancer have more confidence in early screening and treatment options than those at risk for breast/ovarian cancer.

\section{Family relationships}

Genetic counselling was found to have had a negative impact on family relationships in only $5 \%$ of the cases. The impact might have been larger during the first year, with difficulties in family communication decreasing over time. We are currently conducting a longitudinal study of the psychosocial and behavioural impact of genetic counselling for colorectal cancer. In this study, we will be able to identify prospectively the important predictors of distress and family functioning, and to explore the effect of time on psychosocial well-being in more detail.

\section{Social consequences}

Only a few counselees reported having experienced problems in obtaining life insurance $(8 \%)$, choice or change of employment (2\%), or obtaining a mortgage (2\%). These low levels could be due to the fact that, in the Netherlands, there is universal health insurance coverage, and disclosure of genetic status can only be requested when obtaining a mortgage or life-insurance valued at more than 160,000 Euros. 
None of the carriers in our study reported negative consequences for family planning. This is in contrast to the results reported by Smith et al. in a study of women at risk for breast cancer [36]. This difference might be explained by cultural differences between the U.S. and the Netherlands and/or differences in cancer type.

\section{Strengths and limitations of the study}

The high response rate (81\%) suggests that the results are representative of the population requesting genetic counselling and testing for colorectal cancer. The followup period (up to 11 years) is among the longest reported in the literature. However, due to the cross-sectional study design, one can only speak in terms of associations between various "predictor variables" and distress. Without pre-counselling data, it is not possible to establish with certainty whether the results reflect change from pre-counselling levels of distress. Nevertheless, our data indicate that, in the long-term, only a small minority of individuals suffer from clinically significant levels of cancer-specific distress. This contrasts with the literature on the short-term prevalence of distress, where it is reported that as many as one-quarter of individuals who have undergone genetic counselling and/or testing for colorectal cancer experience high levels of distress. Similarly, while we recognize the limitations of retrospective, self-report data on changes in family relationships, it is encouraging that only $5 \%$ of individuals perceived genetic counselling as having had a negative impact on this important area of their lives. Given the potential impact of genetic counselling for families, we would encourage the development of more detailed, standardized questionnaires to assess the impact of genetic counselling on family relationships.

Finally, clinical workers should be aware that counselees who have been in contact with a professional psychosocial worker in relation to their cancer risk during the past 10 years may be at increased risk of experiencing higher levels of distress over the subsequent years. This knowledge can be used as a tool to identify counselees who might benefit from professional psychosocial support during the genetic counselling and testing process.

\section{Acknowledgements}

This study was supported financially by the Netherlands Cancer Institute and the Dutch Cancer Society (grant number KWF-98-1858).

\section{References}

1. Lynch HT, de la Chapelle A. Hereditary colorectal cancer. N Eng J Med 2003; 348: 919-932.
2. Slattery ML, Kerber RA. Family history of cancer and colon cancer risk: the Utah Population Database. J Natl Cancer Inst 1994; 86: 1618-1626.

3. Petersen GM, Brensinger JD, Johnson KA, Giardiello FM. Genetic testing and counseling for hereditary forms of colorectal cancer. Cancer 1999; 86 (1 1 Suppl): 2540-2550.

4. Leach FS, Nicolaides NC, Papadopoulos N, Liu B, Jen J, Parsons R, Peltomaki P, Sistonen P, Aaltonen LA, Nystrom-Lahti M, et al. Mutations of a mutS homolog in hereditary nonpolyposis colorectal cancer. Cell 1993; 75: 1215-1225.

5. Fishel R, Lescoe MK, Rao MR, Copeland NG, Jenkins NA, Garber J, Kane M, Kolodner R. The human mutator gene homolog MSH2 and its association with hereditary nonpolyposis colon cancer. Cell 1994; 77: 167.

6. Papadopoulos N, Nicolaides NC, Wei YF, Ruben SM, Carter KC, Rosen CA, Haseltine WA, Fleischmann RD, Fraser CM, Adams $\mathrm{MD}$, et al. Mutation of a mutL homolog in hereditary colon cancer. Science 1994; 263: 1625-1629.

7. Bronner CE, Baker SM, Morrison PT, Warren G, Smith LG, Lescoe MK, Kane M, Earabino C, Lipford J, Lindblom A, et al. Mutation in the DNA mismatch repair gene homologue hMLHI is associated with hereditary non-polyposis colon cancer. Nature 1994; 368: 258-261

8. Vasen HF, Wijnen JT, Menko FH, Kleibeuker JH, Taal BG, Griffioen G, Nagengast FM, Meijers-Heijboer EH, Bertario L, Varesco L, Bisgaard ML, Mohr J, Fodde R, Khan PM. Cancer risk in families with hereditary nonpolyposis colorectal cancer diagnosed by mutation analysis. Gastroenterology 1996; 110 : 1020-1027.

9. Vasen HF, Mecklin JP, Khan PM, Lynch HT. The International Collaborative Group on Hereditary Non- Polyposis Colorectal Cancer (ICG-HNPCC). Dis Colon Rectum 1991; 34: 424-425.

10. Vasen HF, Nagengast FM, Khan PM. Interval cancers in hereditary non-polyposis colorectal cancer (Lynch syndrome). Lancet 1995; 345: 1183-1184.

1 1. Bleiker EM, Menko FH, Taal BG, Kluijt I, Wever LD, Gerritsma MA, Vasen HF, Aaronson NK. Screening behavior of individuals at high risk for colorectal cancer. Gastroenterology 2005; 128: 280-287.

12. Broadstock M, Michie S, Marteau T. Psychological consequences of predictive genetic testing: a systematic review. Eur J Hum Gen 2000; 8: 731-738.

13. Braithwaite D, Emery J, Walter F, Prevost AT, Sutton S. Psychological impact of genetic counseling for familial cancer: a systematic review and meta-analysis. J Natl Cancer Inst 2004; 96: 122-133.

14. Meiser B, Collins V, Warren R, Gaff C, St John DJ, Young MA, Harrop K, Brown J, Halliday J. Psychological impact of genetic testing for hereditary non-polyposis colorectal cancer. Clin Genet 2004; 66: 502-511.

15. Liliegren A, Lindgren G, Brandberg Y, Rotstein S, Nilsson B, Hatschek $T$, Jaramillo $E$, Lindblom A. Individuals with an increased risk of colorectal cancer: perceived benefits and psychological aspects of surveillance by means of regular colonoscopies. J Clin Oncol 2004; 22: 1736-1742.

16. Esplen MJ, Madlensky L, Butler K, McKinnon W, Bapat B, Wong J, Aronson M, Gallinger S. Motivations and psychosocial impact of genetic testing for HNPCC. Am J Med Genet 2001; 103: 9-15.

17. Keller M, Jost R, Haunstetter CM, Kienle P, Knaebel HP, Gebert J, Sutter C, Knebel-Doeberitz M, Cremer F, Mazitschek U. Comprehensive genetic counseling for families at risk for HNPCC: impact on distress and perceptions. Genet Test 2002; 6: 291-302.

18. Vernon SW, Gritz ER, Peterson SK, Amos Cl, Perz CA, Baile WF, Lynch PM. Correlates of psychologic distress in colorectal cancer patients undergoing genetic testing for hereditary colon cancer. Health Psychol 1997; 16: 73-86. 
19. Gritz ER, Peterson SK, Vernon SW, Marani SK, Baile WF, Watts BG, Amos Cl, Frazier ML, Lynch PM. Psychological impact of genetic testing for hereditary nonpolyposis colorectal cancer. J Clin Oncol 2005; 23: 1902-1910.

20. Aktan-Collan K, Haukkala A, Mecklin JP, Uutela A, Kaariainen $H$. Psychological consequences of predictive genetic testing for hereditary non-polyposis colorectal cancer (HNPCC): a prospective follow-up study. Int J Cancer 2001; 93: 608-61 1 .

21. Claes E, Denayer L, Evers-Kiebooms G, Boogaerts A, Legius E. Predictive testing for hereditary non-polyposis colorectal cancer: motivation, illness representations and short-term psychological impact. Patient Educ Couns 2004; 55: 265-274.

22. Claes E, Evers-Kiebooms G, Denayer L, Decruyenaere M, Boogaerts A, Philippe K, Legius E. Predictive genetic testing for hereditary breast and ovarian cancer: psychological distress and illness representations 1 year following disclosure. J Genet Couns 2005; 14: 349-363.

23. Collins V, Halliday J, Warren R, Williamson R. Cancer worries, risk perceptions and associations with interest in DNA testing and clinic satisfaction in a familial colorectal cancer clinic. Clin Genet 2000; 58: 460-468.

24. Hopwood P. Psychosocial aspects of risk communication and mutation testing in familial breast-ovarian cancer. Curr Opin Oncol 2005; 17: 340-344

25. Richards M. Families, kinship and genetics. In: Marteau T, Richards M, editors. The Troubled Helix: Social and Psychological Implications of the New Human Genetics. Cambridge University Press 1996; 249-273.

26. Peterson SK, Watts BG, Koehly LM, Vernon SW, Baile WF, Kohlmann WK, Gritz ER. How families communicate about HNPCC genetic testing: findings from a qualitative study. Am J Med Genet C Semin Med Genet 2003; 119: 78-86.

27. Mesters I, Ausems M, Eichhorn S, Vasen H. Informing one's family about genetic testing for hereditary non-polyposis colorectal cancer (HNPCC): a retrospective exploratory study. Fam Cancer 2005; 4: 163-167.

28. Claes E, Evers-Kiebooms G, Boogaerts A, Decruyenaere M, Denayer L, Legius E. Communication with close and distant relatives in the context of genetic testing for hereditary breast and ovarian cancer in cancer patients. Am J Med Genet 2003 116:11-19.

29. Hughes C, Lerman C, Schwartz M, Peshkin BN, Wenzel L, Narod S, Corio C, Tercyak KP, Hanna D, Isaacs C, Main D. All in the family: evaluation of the process and content of sisters' communication about BRCA1 and BRCA2 genetic test results. Am J Med Genet 2002; 107: 143-150.

30. DudokdeWit AC, Tibben A, Frets PG, Meijers-Heijboer EJ, Devilee P, Klijn JG, Oosterwijk JC, Niermeijer MF. BRCA1 in the family: a case description of the psychological implications. Am J Med Genet 1997; 71: 63-71

31. Wilson BJ, Forrest K, van Teijlingen ER, McKee L, Haites N, Matthews $E$, Simpson SA. Family communication about genetic risk: the little that is known. Community Genet 2004; 7: 15-24.

32. Bassford TL, Hauck L. Human Genome Project and cancer: the ethical implications for clinical practice. Semin Oncol Nurs 1993; 9: 134-138.

33. Norum J, Tranebjaerg L. Health, life and disability insurance and hereditary risk for breast or colorectal cancer. Acta Oncol 2000; 39: 189-93.

34. Armstrong K, Weber B, Fitzgerald G, Hershey JC, Pauly MV Lemaire J, Subramanian K, Asch DA. Life insurance and breas cancer risk assessment: adverse selection, genetic testing decisions, and discrimination. Am J Med Genet A 2003; 120: 359-364.

35. Aktan-Collan K, Haukkala A, Kaariainen H. Life and health insurance behaviour of individuals having undergone a predictive genetic testing programme for hereditary non-polyposis colorectal cancer. Community Genet 2001; 4: 219-224.

36. Smith KR, Ellington L, Chan AY, Croyle RT, Botkin JR. Fertility intentions following testing for a BRCAl gene mutation. Cancer Epidemiol Biomarkers Prev 2004; 13: 733-740.

37. Lerman C, Seay J, Balshem A, Audrain J. Interest in genetic testing among first-degree relatives of breast cancer patients. Am J Med Genet 1995; 57: 385-392.

38. Wellisch DK, Gritz ER, Schain W, Wang HJ, Siau J. Psychological functioning of daughters of breast cancer patients. Part II: Characterizing the distressed daughter of the breast cancer patient. Psychosomatics 1992; 33: 171-179.

39. Horowitz M, Wilner N, Alvarez W. Impact of Event Scale: a measure of subjective stress. Psychosom Med 1979; 41: 209-218.

40. Brom D, Kleber RJ. De schok verwerkingslijst [Impact of Event Scale]. Ned Tijdschr Psychol 1985; 40: 164-168.

41. Zakowski SG, Valdimarsdottir HB, Bovbjerg DH, Borgen P, Holland J, Kash K, Miller D, Mitnick J, Osborne M, Van Zee K. Predictors of intrusive thoughts and avoidance in women with family histories of breast cancer. Ann Behav Med 1997; 19: 362-369.

42. Thewes B, Meiser B, Hickie IB. Psychometric properties of the Impact of Event Scale amongst women at increased risk for hereditary breast cancer. Psychooncology 2001; 10: 459-468.

43. Horowitz MJ. Stress response syndromes and their treatment. In: Goldberger L, Breznitz S, editors. Handbook of Stress: Theoretical and Clinical Aspects. The Free Press 1982; 711-732.

44. Kaasa S, Malt U, Hagen S, Wist E, Moum T, Kvikstad A. Psychological distress in cancer patients with advanced disease. Radiother Oncol 1993; 27: 193-197.

45. van Tulder MW, Aaronson NK, Bruning PF. The quality of life of long-term survivors of Hodgkin's disease. Ann Oncol 1994; 5: 153-158.

46. Coyne JC, Benazon NR, Gaba CG, Calzone K, Weber BL. Distress and psychiatric morbidity among women from high-risk breast and ovarian cancer families. J Consult Clin Psychol 2000; 68: 864-874

47. Keller M, Henrich G. Illness-related distress: does it mean the same for men and women? Gender aspects in cancer patients' distress and adjustment. Acta Oncol 1999; 38: 747-755.

48. Lengua LJ, Stormshak EA. Gender, Gender roles, and Personality: Gender Differences in the Prediction of Coping and Psychological Symptoms. Sex Roles 2000; 43: 787-820.

49. McDonough P, Walters V. Gender and health: reassessing patterns and explanations. Soc Sci Med 2001 ; 52: 547-559.

50. Northouse LL, Mood D, Templin T, Mellon S, George T. Couples' patterns of adjustment to colon cancer. Soc Sci Med 2000; 50: $271-284$.

51. Lerman C, Schwartz M. Adherence and psychological adjustment among women at high risk for breast cancer. Breast Cancer Res Treat 1993; 28: 145-155. 